\title{
Evaluation of Foliar Diseases for Soybean Entries in the Pan-African Trials in Malawi and Zambia
}

\author{
Christabell Nachilima, ${ }^{1}$ Godfree Chigeza, ${ }^{1}$ Mwila Chibanda, ${ }^{2}$ Hapson Mushoriwa, ${ }^{3}$ Brian D. Diers, ${ }^{4}$ Harun M. Murithi, ${ }^{5}$ \\ and Glen L. Hartman ${ }^{4,5, \dagger}$ \\ ${ }^{1}$ International Institute of Tropical Agriculture-IITA SARAH Campus, Lusaka, Zambia \\ ${ }^{2}$ SeedCo Research Station, Lusaka, Zambia \\ ${ }^{3}$ Rattray Arnold Research Station, Harare, Zimbabwe \\ ${ }^{4}$ Department of Crop Sciences, University of Illinois Urbana, Urbana, IL 61801, U.S.A. \\ ${ }^{5}$ USDA, Agricultural Research Service, Urbana, IL 61801, U.S.A.
}

\begin{abstract}
Soybean production has expanded worldwide including countries in sub-Saharan Africa. Several national and international agencies and research groups have partnered to improve overall performance of soybean breeding stocks and have introduced new germplasm from Brazil and the United States with the goal of developing new highyielding cultivars. Part of this effort has been to test improved soybean lines/cultivars accumulated from private and public sources in multilocational trials in sub-Saharan Africa. These trials are known as the PanAfrican Soybean Variety Trials, and the entries come from both private and public breeding programs. The objective of this research was to

Zambia and one in Malawi. Plants were evaluated during the reproductive growth stages using a visual pretransformed severity rating scale. Foliar disease ratings were recorded for three bacterial diseases, six fungal diseases, one oomycete, and viruses. The overall occurrence of most of the diseases was high except for soybean rust and target spot, which were only found at two and one location, respectively. However, disease severity was generally low, although there were differences in disease severity ratings among the entries at some of the locations for brown spot, downy mildew, frogeye leaf spot, red leaf blotch, and soybean rust.
\end{abstract} evaluate entries in the trials that include commercial cultivars or advanced experimental lines for the incidence and severity of foliar diseases. All trials were planted in December 2018 with six located in
Keywords: fungi, field crops, oilseeds and legumes, disease management, cultivar/resistance
Soybean production occurs throughout sub-Saharan African countries, with Nigeria and South Africa, respectively, leading production with 1.32 and 0.73 million metric tons based on data from 2017 (FAOSTAT 2019). The total production of soybean in Africa was 3.13 million metric tons in 2017, representing a 5.8-fold increase over 30 years, which is greater than the 3.8 -fold increase for world production during the same time period. Still, soybean production in Africa represents about $1 \%$ of the global production based on 2017 data (FAOSTAT 2019).

${ }^{\dagger}$ Corresponding author: G. L. Hartman; Glen.Hartman@ars.usda.gov, ghartman@illinois.edu

Trade and manufacturers' names are necessary to report factually on available data; however, the USDA neither guarantees nor warrants the standard of the product, and the use of the name by USDA implies no approval of the product to the exclusion of others that may also be suitable.

Funding: This research was supported by the Feed the Future Innovation Lab for Soybean Value Chain Research (Soybean Innovation Lab) under the U.S. Government's global hunger and food security initiative, Feed the Future. The Soybean Innovation Lab is managed by the University of Illinois at UrbanaChampaign through support from the U.S. Agency for International Development (USAID) (Award No. AID-OAA-L-14-00001; P. Goldsmith, PI).

The author(s) declare no conflict of interest.

Accepted for publication 27 February 2020.

This article is in the public domain and not copyrightable. It may be freely reprinted with customary crediting of the source. The American Phytopathological Society, 2020.
Soybean production in Africa is considered important to farmers with smaller hectarage (Chigeza et al. 2019). Part of the push to increase soybean production in Africa comes from the Feed the Future Innovation Lab for Soybean Value Chain Research, Soybean Innovation Lab, whose mission is to build a foundation for soybean production by developing the knowledge, innovation, and technologies to enable successful and sustainable soybean production. As part of this initiative, the Soybean Innovation Lab has partnered with the International Institute of Tropical Agriculture (IITA) and other agencies to evaluate soybean performance in multiple locations in Africa. The soybeans used for testing include IITA breeding stock, nationally released cultivars, and introduced germplasm from Brazil, the United States, and other countries with the goal of developing and releasing new high-yielding cultivars. Part of this effort has been to develop multilocational trials across sub-Saharan Africa so soybean lines/cultivars can be widely tested in multiple countries. These trials are known as the Pan-African Soybean Variety Trials or the PanAfrican Trials (Santos 2019).

Disease and pest problems have been documented for soybeans grown in Africa, with perhaps the earliest report in 1919 that included "black mildew", "blight", and "rust" (Shurtleff and Aoyagi 2009). With the intent to increase production in many new areas, management of diseases and pests, especially in a sustainable manner such as breeding for resistance, has gained more interest. The majority of soybean diseases in Africa are not new and occur in other continents with a few exceptions (Hartman 2015). Diseases of importance in Africa include frogeye leaf spot, red leaf blotch, rust, sudden death syndrome in certain counties, and a few other diseases that may be considered major or minor (Hartman and Murithi 2019), depending on their geographical distribution and economic impact. For the most part, soybean disease distribution over sub-Saharan Africa is 
unknown, although there is some information on the distribution of soybean rust (Hartman and Murithi 2018; Murithi et al. 2015, 2017). The distribution of soybean diseases has likely changed over time and space, and sources of obtaining updates on outbreaks of diseases and pests of soybean in Africa is lacking.

Some regions in African countries have grown soybean extensively in rotation with other crops for a number of decades, but in other regions, soybean is a relatively new crop. In some cases, diseases may be introduced with the crop either through seeds, vectors, or human activity. In other cases, the pathogen may be present on another host, and when soybean is introduced, the pathogen may infect soybean. This seems to be the case for the fungal pathogen causing red leaf blotch of soybean, which appears to be endemic in subSaharan Africa and infected soybean when the crop was introduced (Hartman et al. 1987). Of the diseases that occur in Africa, red leaf blotch could become a major threat to soybean production in the United States if it were introduced (Hartman et al. 2009), and unlike most other diseases of soybean in Africa, there may be limited sources of resistance (Tooley 2017). Diseases of unknown distribution and importance in Africa that have been recently reported include bacterial tan spot (Pawlowski and Hartman 2019), Fusarium root rot complex (Hartman et al. 2019), Myrothecium leaf spot (Haudenshield et al. 2018), and Sclerotinia stem rot (Pawlowski et al. 2019).

Disease and pest resistance in soybean have been an effective tool along with other management options to reduce potential losses. The discovery and introgression of disease and pest resistance genes provide benefits to yield gain and crop stability (Hartman et al. 2015). Most commercial soybean cultivars grown in the United States today include resistance to one or more pathogens or pests (Chawla et al. 2013). Soybean growers have options to select commercial cultivars with resistance (sometimes referred to as tolerance) to bacterial blight, bacterial pustule, brown stem rot, downy mildew, frogeye leaf spot, Phytophthora root and stem rot, Sclerotinia stem rot, soybean aphid, soybean cyst nematode, stem canker, and sudden death syndrome. For some diseases, such as anthracnose, brown spot, Cercospora leaf blight, charcoal rot, Phomopsis seed decay, and pod and stem blight, resistant cultivars have yet to be advertised by private companies. In Africa, most of the aforementioned diseases have been reported, but there is little information on whether there is resistance to strains of the pathogens in sub-Saharan Africa. The objective of this research was to evaluate commercial or near-commercial soybean cultivars adapted to sub-Saharan African conditions for the incidence and severity of foliar diseases.

\section{Materials and Methods}

Soybean entries in the Pan-African Trials. The soybean entries in this study were soybean cultivars and experimental lines from private and public sources (Table 1). Most of the entries were bred for subtropical to tropical conditions. Entries from private companies included nominations of proprietary cultivars and experimental lines; the public soybean entries were selected on the basis of previously being grown in that region or being developed through breeding programs such as IITA (Chigeza et al. 2019). Seeds used to plant the tests were multiplied in bulk by IITA and harvested in 2018. The seeds were packaged at IITA Lusaka and sent out to the various cooperators for planting at the specified locations (Table 1).

Experiment locations and design. Six of the seven trial locations were in Zambia with one in Malawi, and all were planted in December 2018 (Table 1). Trials were in a randomized complete block design with four replications. The trials planted at locations $1,3,6$, and 7 were in four-row plots, whereas locations 4 and 5 were six-row plots. Rows were $5 \mathrm{~m}$ in length with a row spacing of $50 \mathrm{~cm}$ and 20 seeds planted per meter of row. Seeds were treated with bacterial inoculant before planting but not with biological or chemical seed protectants. Soya mix fertilizer (7:20:70 N/P/K) was applied at planting at $200 \mathrm{~kg} / \mathrm{ha}$. Pre- and postemergence weed control consisted of imidazolinone (100 g/liter), metolachlor (960 g/liter), quizalofop- $p$ ethyl (35 g/liter), and fomesafen (125 g/liter), and hand-weeding. For the control of insects, lambda-cyhalothrin ( $50 \mathrm{~g} /$ liter) was applied once at growth stage from R6 to R7 (Fehr et al. 1971) at each location except at Lusaka IITA, where it was applied twice at growth stages R3 and R6.

Disease and pest evaluations. Plants were evaluated in plots once when they were in the mid to late pod filling stages using a visual severity rating for each disease and insect foliar feeding damage (IFFD) per plot using a pretransformed rating scale (Little and Hills 1978) from 0 to 5 , where $0=$ no visible symptoms, $1=1$ to $10 \%$ of the canopy affected, $2=11$ to $35 \%$ of the canopy affected, $3=36$ to $65 \%$ of the canopy affected, $4=66$ to $90 \%$ of the canopy affected, and $5=91$ to $100 \%$ of the canopy affected. Disease incidence was scored 0 to 1 based on absence or presence, respectively, of the disease in the plot. Data were recorded for two replications at each location and included growth stage; leaf diseases caused by bacteria, fungi, viruses, and an unknown disorder with symptoms we refer to as "mustard leaf spot" (Fig. 1); and IFFD (holes in leaves) (Table 2). In addition, at one

Table 1. Soybean entries from the Pan-African Trials grown in Malawi and Zambia and evaluated for foliar disease for the 2018 to 2019 growing season

\begin{tabular}{|c|c|c|}
\hline Entry & Location $^{z}$ & Source \\
\hline Clark $63 \mathrm{k}$ & $1-3,5,6,8,9$ & Ethiopian Institute of Agricultural Research \\
\hline Dundee & 2,8 & Agriculture Research Council, South Africa \\
\hline Egret & 2,8 & Agriculture Research Council, South Africa \\
\hline Gazelle & $6,8,9$ & $\begin{array}{l}\text { Kenya Agricultural \& Livestock Research } \\
\text { Organization }\end{array}$ \\
\hline Heron & 2,8 & $\begin{array}{l}\text { Kenya Agricultural \& Livestock Research } \\
\text { Organization }\end{array}$ \\
\hline Ibis 2000 & 2,8 & Agriculture Research Council, South Africa \\
\hline Kaleya & $1-3,5,6,8,9$ & ZamSeed, Zambia \\
\hline Lukanga & $1-3,5,6,8,9$ & ZamSeed, Zambia \\
\hline Maksoy $5 \mathrm{~N}$ & $1-3,5,6,8,9$ & Makerere University, Uganda \\
\hline Makwacha & $1-3,5,6,8,9$ & $\begin{array}{l}\text { Department of Agricultural Research } \\
\text { Services, Malawi }\end{array}$ \\
\hline MRI Dina & $1,3,5,6,8,9$ & MRI/Syngenta, Zambia \\
\hline Nasoko & $1-3,5,6,8,9$ & $\begin{array}{l}\text { Department of Agricultural Research } \\
\text { Services, Malawi }\end{array}$ \\
\hline
\end{tabular}

Panorama $291 \quad 1-3,5,6,8,9$ Semillas Panorama SAS, Columbia

Panorama $3 \quad 1-3,5,6,8,9$ Semillas Panorama SAS, Columbia

Panorama 358 1-3, 5, 6, 8, 9 Semillas Panorama SAS, Columbia

S1079-6-7 1-3, 5, 6, 8, 9 SeedCo, Zimbabwe

S1187-5-37 1, 2, 3, 5 SeedCo, Zimbabwe

S1150-5-22 1-3, 5, 6, 8, 9 SeedCo, Zimbabwe

S1180-5-54 1-3, 5, 6, 8, 9 SeedCo, Zimbabwe

S2246-5-25 1, 2, 3 SeedCo, Zimbabwe

Safari $\quad 1-3,5,6,8,9$ SeedCo, Zimbabwe

SC Saga $\quad 1-3,5,6,8,9$ SeedCo, Zimbabwe

(check)

SC Sentinel 1-3, 5, 6, 8, 9 SeedCo, Zimbabwe

SC Signal $\quad 1-3,5,6,8,9$ SeedCo, Zimbabwe

SC Spike $\quad 1-3,5,6,8,9$ SeedCo, Zimbabwe

SCS-1 1-3, 5, 6, 8, 9 Ethiopian Institute of Agricultural Research

SNK500 1-3, 5, 6, 8, 9 Sensako, South Africa

SNKM004 5, 6, 8, 9 Sensako, South Africa

TGX 1987-62F 1-3, 5, 6, 8, 9 International Institute of Tropical Agriculture, Nigeria

TGX 1991-22F 1-3, 5, 6, 8, 9 International Institute of Tropical Agriculture, Nigeria

TGx2002-35FM 1, 3, 5, 6, 9 International Institute of Tropical Agriculture, Nigeria

TGx2002-9FM 1, 3, 5, 6, 9 International Institute of Tropical Agriculture, Nigeria

TGx2014-16FM 1-3, 5, 6, 8, 9 International Institute of Tropical Agriculture, Nigeria

TGx2014-21FM 1, 3, 5, 6, 9 International Institute of Tropical Agriculture, Nigeria

Tikolore $\quad 1-3,5,6,8,9$ Department of Agricultural Research Services, Malawi

${ }^{\mathrm{z}}$ Locations: 1 = Lusaka IITA; 2 = Chitedze, Malawi; 3 = Lusaka Syngenta; 5 = Lusaka SeedCo; $6=$ Mpongwe; $8=$ Chipata; and $9=$ Kabwe were planted in 2019 on December 6, 19, 12, 15, 21, 7, and 27, respectively. 
location, Chitedze, rust reaction type was recorded as tan (TAN) or red brown (RB) based on previous descriptions of reaction types (Miles et al. 2011).

Data analysis. Restricted or residual maximum likelihood (REML) analysis of the ratings for each of the seven locations was done with JMP Pro version 13 (SAS Institute, Cary, NC). The soybean entries were considered as fixed effects as well as locations when data were combined. Replications were random effects. When significant differences were identified in the REML analyses, least square means were separated using least significant difference at $\alpha=0.05$. Pairwise correlation coefficients were calculated with the PROC CORR procedure.

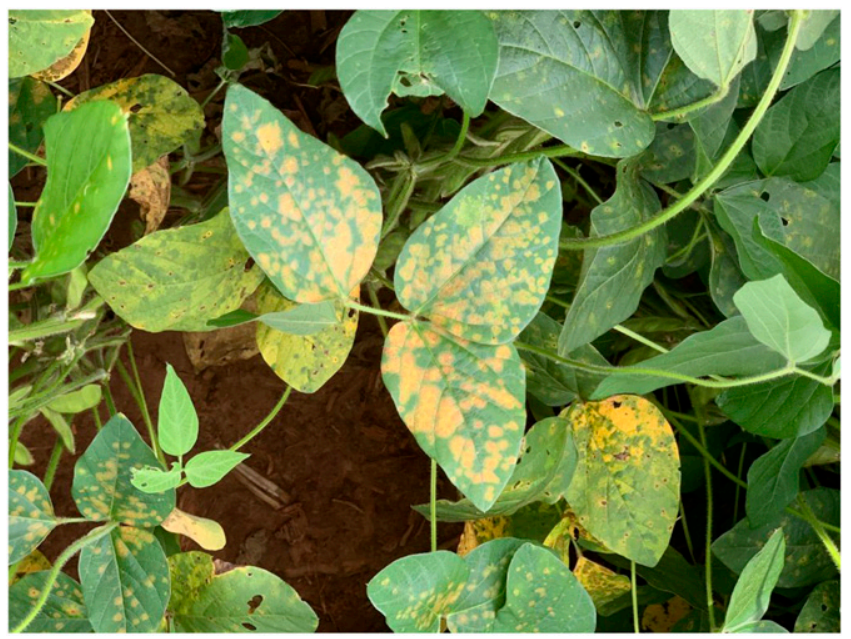

Fig. 1. Mustard leaf spot of soybean, a disorder of unknown etiology.

\section{Results}

General overview. The planting dates varied some by locations (Table 1) with a difference of 21 days from earliest to the latest planted location. Evaluations of these trials were recorded over a 7-day period with the average growth stage ranging from full pod (growth stage R4) at Kabwe to full seed (growth stage R6) at Chipata (Table 2).

Foliar disease symptoms were recorded for three bacterial diseases, six fungal diseases, one oomycete, and viruses (not differentiated into species). IFFD and mustard leaf spot were also recorded. Disease incidence of all disease occurred at most locations; however, there was low incidence of target spot (recorded at only one location) and soybean rust (recorded at only two locations).

Bacterial foliar diseases. The three bacterial diseases were generally light and did not occur at all locations (Table 2). The average incidence over locations for blight, pustule, and tan spot were 71, 57, and $71 \%$, respectively. The average severity ratings over locations for blight, pustule, and tan spot were $0.5,0.3$, and 0.4 , respectively. The only location that was analyzed for entry effect was for bacterial tan spot (average severity was 1.4 with all but two experimental units having a rating) at Lusaka IITA; however, the ANOVA did not show an entry difference $(P<0.19$; data not shown). Line TGX 1991-22F had the lowest severity rating (0), whereas SC Saga had the highest severity rating (2.5).

Fungal and fungal-like foliar diseases. Brown spot was recorded in all but two locations (Table 2). Data from the Lusaka IITA location were analyzed because the disease severity averaged 1.6 and there was a significant $(P<0.002)$ entry effect. Severity ranged from 0 to 2.5 (Table 3 ). Panorama 3 had the lowest severity rating at 0.5 , which was not different from 18 other entries in the trial.

Downy mildew was recorded in all but two locations (Table 2). Data from the Kabwe location were analyzed because the disease severity averaged 1.5 and there was a significant $(P<0.0001)$ entry effect. Severity ranged from 0 to 3.0. The entry Lukanga had the lowest severity, which was not different from four other entries in the trial (Table 3).

Table 2. Mean severity ratings ( 0 to 5 scale) \pm their standard errors and incidence of foliar abnormalities of soybean entries grown in the Pan-African Trials in Malawi and Zambia for the 2018 to 2019 growing season

\begin{tabular}{|c|c|c|c|c|c|c|c|}
\hline \multirow[b]{2}{*}{ Location } & \multicolumn{7}{|c|}{ Growth stage (GS) and foliar ratings of nonfungal diseases ${ }^{y}$} \\
\hline & GS & MLS & BB & BP & BTS & Virus & IFFD \\
\hline Chipata & $5.7 \pm 0.11$ & $0.2 \pm 0.06$ & $0.0 \pm 0.00$ & $0.1 \pm 0.03$ & $0.1 \pm 0.04$ & $0.0 \pm 0.02$ & $1.3 \pm 0.06$ \\
\hline Chitedze & $4.6 \pm 0.12$ & $0.6 \pm 0.10$ & $0.1 \pm 0.04$ & $0.3 \pm 0.08$ & $0.3 \pm 0.06$ & $0.2 \pm 0.06$ & $1.0 \pm 0.02$ \\
\hline Kabwe & $3.8 \pm 0.08$ & $0.3 \pm 0.06$ & $0.0 \pm 0.02$ & $0.0 \pm 0.00$ & $0.0 \pm 0.02$ & $0.3 \pm 0.07$ & $1.9 \pm 0.07$ \\
\hline Lusaka IITA & $5.1 \pm 0.12$ & $0.0 \pm 0.00$ & $0.9 \pm 0.04$ & $0.1 \pm 0.05$ & $1.4 \pm 0.08$ & $0.0 \pm 0.02$ & $1.0 \pm 0.04$ \\
\hline Lusaka Syngenta & $4.5 \pm 0.11$ & $0.3 \pm 0.06$ & $0.6 \pm 0.06$ & $0.4 \pm 0.07$ & $0.0 \pm 0.00$ & $0.1 \pm 0.04$ & $1.4 \pm 0.09$ \\
\hline Lusaka West & $5.4 \pm 0.15$ & $0.2 \pm 0.05$ & $0.5 \pm 0.11$ & $0.0 \pm 0.02$ & $0.1 \pm 0.03$ & $0.1 \pm 0.04$ & $1.4 \pm 0.08$ \\
\hline Mpongwe & $4.0 \pm 0.07$ & $0.7 \pm 0.12$ & $0.4 \pm 0.06$ & $0.0 \pm 0.00$ & $0.1 \pm 0.05$ & $0.3 \pm 0.07$ & $1.0 \pm 0.07$ \\
\hline Severity & & 0.3 & 0.5 & 0.3 & 0.4 & 0.1 & 1.3 \\
\hline Incidence (\%) & $\ldots$ & 86 & 71 & 57 & 71 & 71 & 100 \\
\hline
\end{tabular}

\begin{tabular}{|c|c|c|c|c|c|c|c|}
\hline \multirow[b]{2}{*}{ Location } & \multicolumn{7}{|c|}{ Fungal and fungal-like diseases ${ }^{\mathrm{z}}$} \\
\hline & BS & CLB & DM & FELS & RLB & SBR & TS \\
\hline Chipata & $0.0 \pm 0.00$ & $0.6 \pm 0.11$ & $0.4 \pm 0.11$ & $0.1 \pm 0.03$ & $0.2 \pm 0.05$ & $1.9 \pm 0.13$ & $0.0 \pm 0.00$ \\
\hline Chitedze & $0.1 \pm 0.04$ & $0.3 \pm 0.08$ & $0.7 \pm 0.11$ & $0.0 \pm 0.00$ & $0.1 \pm 0.04$ & $2.7 \pm 0.10$ & $0.6 \pm 0.10$ \\
\hline Kabwe & $0.0 \pm 0.00$ & $0.1 \pm 0.04$ & $1.5 \pm 0.10$ & $0.1 \pm 0.04$ & $0.1 \pm 0.04$ & $0.0 \pm 0.00$ & $0.0 \pm 0.00$ \\
\hline Lusaka IITA & $1.6 \pm 0.09$ & $0.3 \pm 0.07$ & $0.6 \pm 0.09$ & $0.1 \pm 0.03$ & $0.6 \pm 0.07$ & $0.0 \pm 0.00$ & $0.0 \pm 0.03$ \\
\hline Lusaka Syngenta & $1.0 \pm 0.14$ & $0.2 \pm 0.06$ & $0.3 \pm 0.06$ & $0.6 \pm 0.09$ & $1.2 \pm 0.09$ & $0.0 \pm 0.00$ & $0.0 \pm 0.00$ \\
\hline Lusaka West & $0.1 \pm 0.04$ & $0.2 \pm 0.07$ & $0.4 \pm 0.09$ & $0.0 \pm 0.00$ & $1.9 \pm 0.10$ & $0.0 \pm 0.00$ & $0.0 \pm 0.00$ \\
\hline Mpongwe & $0.0 \pm 0.02$ & $0.1 \pm 0.03$ & $1.0 \pm 0.09$ & $1.9 \pm 0.18$ & $0.6 \pm 0.07$ & $0.0 \pm 0.00$ & $0.0 \pm 0.00$ \\
\hline Severity & 0.4 & 0.3 & 0.5 & 0.3 & 0.4 & 0.5 & 0.1 \\
\hline Incidence $(\%)$ & 57 & 100 & 71 & 57 & 71 & 29 & 14 \\
\hline
\end{tabular}

y GS = reproductive growth stage (Fehr et al. 1971); MLS = mustard leaf spot; BB = bacterial blight; $\mathrm{BP}=$ bacterial pustule; BTS = bacterial tan spot; Virus = virus-like symptoms of foliar mottling; and IFFD = insect foliar feeding damage.

${ }^{\mathrm{z}} \mathrm{BS}=$ brown spot $\mathrm{CLB}=$ Cercospora leaf blight; $\mathrm{DM}=$ downy mildew; FELS = frogeye leaf spot; RLB = red leaf blotch; $\mathrm{SBR}=$ soybean rust; and TS = target spot. 
Frogeye leaf spot was observed at five of the seven locations. Four of the locations with frogeye leaf spot had low severity ratings (Table 2). Mpongwe had the highest rating (1.9) with differences $(P<0.05)$ among entries. Severity ranged from 0 to 3.0 (Table 3$)$. There were seven entries that had ratings that were not different from the lowest rating of 0 , and there were six entries that had ratings that were not different from the highest rating of 4 (Table 3 ).

Red leaf blotch data from the two locations were not combined because there was an interaction $(P<0.05)$ between entry and location. For each location, entry was significant $(P<0.04$ at Lusaka Syngenta and $P<0.001$ at Lusaka SeedCo). The average ratings for red leaf blotch were 1.9 and 1.2 at Lusaka Syngenta and Lusaka West, respectively. Out of the 30 entries, 13 and 19 did not differ from the lowest red leaf blotch rating in Lusaka Syngenta and Lusaka SeedCo, respectively (Table 4). The correlation between the red leaf blotch mean ratings at the two locations was not significant.

Soybean rust data from the two locations (Chipata and Chitedze) were combined because there was no interaction $(P>0.05)$ between entry and location. The average rating for soybean rust was 2.3 with a range from 1.1 to 3.2. The lowest soybean rust rating was SC Signal (rated 1.1), which was not significantly different from nine other entries (Table 5). Entry rust severity means at the two locations were correlated ( $r=0.43, P=0.03)$. For the Chitedze location, the predominant reaction type was TAN, but six entries had an RB reaction type and lower rust severity ratings. Rust reaction type was not rated at Chipata.

Table 3. Brown spot, downy mildew, and frogeye leaf spot ratings ${ }^{\mathrm{y}}$ at Lusaka IITA, Kabwe, and Mpongwe, respectively, in Zambia in 2019

\begin{tabular}{|c|c|c|c|c|c|}
\hline \multicolumn{2}{|c|}{$\begin{array}{l}\text { Brown spot at Lusaka } \\
\text { IITA }\end{array}$} & \multicolumn{2}{|c|}{$\begin{array}{c}\text { Downy mildew at } \\
\text { Kabwe }\end{array}$} & \multicolumn{2}{|c|}{$\begin{array}{c}\text { Frogeye leaf spot at } \\
\text { Mpongwe }\end{array}$} \\
\hline Clark 63k & $2.5 \mathrm{a}^{\mathrm{z}}$ & Clark $63 \mathrm{k}$ & $3.0 \mathrm{a}$ & Clark 63k & $\overline{4.0 \mathrm{a}}$ \\
\hline S1079-6-7 & $2.5 \mathrm{a}$ & Gazelle & $2.5 \mathrm{ab}$ & Nasoko & $4.0 \mathrm{a}$ \\
\hline S1180-5-54 & $2.5 \mathrm{a}$ & Kaleya & $2.5 \mathrm{ab}$ & TGX 1991-22F & $4.0 \mathrm{a}$ \\
\hline S1187-5-37 & $2.5 \mathrm{a}$ & SCS-1 & $2.5 \mathrm{ab}$ & TGx2002-35FM & $4.0 \mathrm{a}$ \\
\hline Safari & $2.5 \mathrm{a}$ & TGx2001-24FM & $2.5 \mathrm{ab}$ & Tikolore & $4.0 \mathrm{a}$ \\
\hline SC Saga & $2.5 \mathrm{a}$ & Makwacha & $2.0 \mathrm{bc}$ & TGX 1987-62F & $3.5 \mathrm{ab}$ \\
\hline Makwacha & $2.0 \mathrm{ab}$ & MRI Dina & $2.0 \mathrm{bc}$ & SNK500 & $3.0 \mathrm{bc}$ \\
\hline TGX 1991-22F & $2.0 \mathrm{ab}$ & Nasoko & $2.0 \mathrm{bc}$ & Lukanga & $2.5 \mathrm{~cd}$ \\
\hline $\begin{array}{l}\text { TGx2002- } \\
\text { 35FM }\end{array}$ & $2.0 \mathrm{ab}$ & Panorama 291 & $2.0 \mathrm{bc}$ & Makwacha & $2.5 \mathrm{~cd}$ \\
\hline Tikolore & $2.0 \mathrm{ab}$ & Panorama 3 & $2.0 \mathrm{bc}$ & Panorama 291 & $2.5 \mathrm{~cd}$ \\
\hline Kaleya & $1.5 \mathrm{a}-\mathrm{c}$ & SC Saga & $2.0 \mathrm{bc}$ & Panorama 3 & $2.5 \mathrm{~cd}$ \\
\hline Lukanga & $1.5 \mathrm{a}-\mathrm{c}$ & TGX 1987-62F & $2.0 \mathrm{~cd}$ & SC Spike & $2.5 \mathrm{~cd}$ \\
\hline Nasoko & $1.5 \mathrm{a}-\mathrm{c}$ & Maksoy 5N & $1.5 \mathrm{~cd}$ & TGx2001-24M & $2.5 \mathrm{~cd}$ \\
\hline S1150-5-22 & $1.5 \mathrm{a}-\mathrm{c}$ & S1079-6-7 & $1.5 \mathrm{~cd}$ & TGx2014-16FM & $2.0 \mathrm{de}$ \\
\hline SC Sentinel & $1.5 \mathrm{a}-\mathrm{c}$ & Safari & $1.5 \mathrm{~cd}$ & Gazelle & $1.5 \mathrm{ef}$ \\
\hline SC Spike & $1.5 \mathrm{a}-\mathrm{c}$ & SNK500 & $1.5 \mathrm{~cd}$ & Kaleya & $1.5 \mathrm{ef}$ \\
\hline TGx2002-9FM & $1.5 \mathrm{a}-\mathrm{c}$ & TGX 199 & $1.5 \mathrm{~cd}$ & Panoram & $1.5 \mathrm{ef}$ \\
\hline Maksoy $5 \mathrm{~N}$ & $1.0 \mathrm{bc}$ & TGx2014-21FM & $1.5 \mathrm{~cd}$ & SC Signal & $1.5 \mathrm{ef}$ \\
\hline MRI Dina & $1.0 \mathrm{bc}$ & Panorama 358 & $1.0 \mathrm{de}$ & Maksoy $5 \mathrm{~N}$ & $1.0 \mathrm{fg}$ \\
\hline Panorama 291 & $1.0 \mathrm{bc}$ & S1150-5-22 & $1.0 \mathrm{de}$ & MRI Dina & $1.0 \mathrm{fg}$ \\
\hline Panorama 358 & $1.0 \mathrm{bc}$ & SC Sentinel & $1.0 \mathrm{de}$ & S1150-5-22 & $1.0 \mathrm{fg}$ \\
\hline S1146-5-25 & $1.0 \mathrm{bc}$ & SNKM004 & $1.0 \mathrm{de}$ & SC Saga & $1.0 \mathrm{fg}$ \\
\hline SC Signal & $1.0 \mathrm{bc}$ & TGx2002-35FM & $1.0 \mathrm{de}$ & SNKM004 & $1.0 \mathrm{fg}$ \\
\hline TGX 1987-62F & $1.0 \mathrm{bc}$ & TGx2014-16FM & $1.0 \mathrm{de}$ & SCS-1 & $0.5 \mathrm{gh}$ \\
\hline TGx2001-24FM & $1.0 \mathrm{bc}$ & Tikolore & $1.0 \mathrm{de}$ & TGx2002-9FM & $0.5 \mathrm{gh}$ \\
\hline TGx2014-16FM & $1.0 \mathrm{bc}$ & S1180-5-54 & 0.5 ef & S1079-6-7 & $0 \mathrm{~h}$ \\
\hline TGx2014-21FM & $1.0 \mathrm{bc}$ & SC Signal & 0.5 ef & S1180-5-54 & $0 \mathrm{~h}$ \\
\hline \multirow[t]{3}{*}{ Panorama 3} & $0.5 \mathrm{c}$ & SC Spike & 0.5 ef & Safari & $0 \mathrm{~h}$ \\
\hline & & TGx2002- & 0.5 ef & SC Sentinel & $0 \mathrm{~h}$ \\
\hline & & Lukanga & $0.0 \mathrm{f}$ & TGx2014-21FM & $0 \mathrm{~h}$ \\
\hline
\end{tabular}

y Data based on a visual severity rating using a pretransformed rating scale from 0 to 5 , where $0=$ no visible symptoms, $1=1$ to $10 \%$ of the canopy affected, $2=11$ to $35 \%$ of the canopy affected, $3=36$ to $65 \%$ of the canopy affected, $4=66$ to $90 \%$ of the canopy affected, and $5=91$ to $100 \%$ of the canopy affected.

${ }^{\mathrm{z}}$ Means followed by different letters within a column are significantly different $(\alpha=0.05)$
Other foliar diseases and damage. Cercospora leaf blight was recorded at all locations but had low severity scores with a range of 0.1 to 0.6 (Table 2). Target leaf spot was recorded in only the Malawi location of Chitedze with a disease severity of 0.6. IFFD was recorded at all seven locations with a range of 1.0 to 1.9 . The highest rating was at Kabwe, but entries did not differ $(P<0.08)$. Mustard leaf spot was recorded at all seven locations except Lusaka IITA and appeared on lower leaves, oftentimes on secondary stems (Fig. 1). The range of ratings was from 0.2 to 0.7 (Table 2) over the locations, and only one location (Mpongwe) was analyzed. The average mustard leaf spot rating was 0.7 , with two entries (TGx2002-9FM and Gazelle) having greater $(P<0.05)$ ratings at 3.5 and 3.0, respectively, than the rest of the entries, which ranged from 0 (13 entries) to 1.5 (data not shown).

Pairwise correlation coefficients to growth stage and foliar ratings indicated that most variables were not correlated with growth stage ratings with some exceptions (Table 6). Those that showed positive correlations included bacterial tan spot (two of six locations), viruses (one of seven locations), brown spot (three of six locations), red leaf blotch (two of seven locations), and soybean rust (one of two locations). Those that showed negative correlations included viruses (one of seven locations) and downy mildew (four of seven locations).

\section{Discussion}

This survey of foliar diseases at one location in Malawi and six locations in Zambia provides insight as to foliar constraints occurring in that region of sub-Saharan Africa. All of the foliar diseases

Table 4. Red leaf blotch ratings averaged over two replications at two locations near Lusaka, Zambia. Data were recorded when entries' average growth stage was 4.5 and 5.4 at Lusaka Syngenta and Lusaka SeedCo Farm, respectively, on March 12 and March 10, 2019.

\begin{tabular}{|c|c|c|}
\hline Entry & Lusaka Syngenta & Lusaka SeedCo \\
\hline Maksoy $5 \mathrm{~N}$ & $3 \mathrm{a}^{\mathrm{y}}$ & $0.5 \mathrm{~d}$ \\
\hline SC Sentinel & $3 \mathrm{a}$ & $1 \mathrm{~cd}$ \\
\hline TGx2002-9FM & $3 \mathrm{a}$ & $1 \mathrm{~cd}$ \\
\hline Lukanga & $2.5 \mathrm{ab}$ & $2 \mathrm{ab}$ \\
\hline Makwacha & $2.5 \mathrm{ab}$ & $1.5 \mathrm{bc}$ \\
\hline S1079-6-7 & $2.5 \mathrm{ab}$ & $1 \mathrm{~cd}$ \\
\hline S1180-5-54 & $2.5 \mathrm{ab}$ & $1 \mathrm{~cd}$ \\
\hline Clark 63k & $2 \mathrm{ab}$ & $1.5 \mathrm{bc}$ \\
\hline Kaleya & $2 a b$ & $1 \mathrm{~cd}$ \\
\hline Nasoko & $2 a b$ & $1 \mathrm{~cd}$ \\
\hline Panorama 291 & $2 \mathrm{ab}$ & $0.5 \mathrm{~d}$ \\
\hline S1150-5-22 & $2 a b$ & $2.5 \mathrm{a}$ \\
\hline S1187-5-37 & $2 a b$ & $1 \mathrm{~cd}$ \\
\hline S2246-5-25 & $2 \mathrm{ab}$ & $0.5 \mathrm{~d}$ \\
\hline SC Saga & $2 a b$ & $1 \mathrm{~cd}$ \\
\hline TGx2002-35FM & $2 \mathrm{ab}$ & $1.5 \mathrm{bc}$ \\
\hline MRI Dina & $1.5 \mathrm{~b}-\mathrm{d}$ & $1.5 \mathrm{bc}$ \\
\hline Panorama 3 & $1.5 \mathrm{~b}-\mathrm{d}$ & $0.5 \mathrm{~d}$ \\
\hline Panorama 358 & $1.5 \mathrm{~b}-\mathrm{d}$ & $0.5 \mathrm{~d}$ \\
\hline S1140-5-4 & $1.5 \mathrm{~b}-\mathrm{d}$ & $2.5 \mathrm{a}$ \\
\hline SC Signal & $1.5 \mathrm{~b}-\mathrm{d}$ & $0.5 \mathrm{~d}$ \\
\hline SC Spike & $1.5 \mathrm{~b}-\mathrm{d}$ & $1 \mathrm{~cd}$ \\
\hline TGx2001-24M & $1.5 \mathrm{~b}-\mathrm{d}$ & $1 \mathrm{~cd}$ \\
\hline TGx2014-16FM & $1.5 \mathrm{~b}-\mathrm{d}$ & $2.5 \mathrm{a}$ \\
\hline TGx2014-21FM & $1.5 \mathrm{~b}-\mathrm{d}$ & $2 \mathrm{ab}$ \\
\hline Tikolore & $1.5 \mathrm{~b}-\mathrm{d}$ & $1 \mathrm{~cd}$ \\
\hline SNK500 & $1 \mathrm{~cd}$ & $1 \mathrm{~cd}$ \\
\hline TGX 1987-62F & $0.5 \mathrm{~d}$ & $1.5 \mathrm{bc}$ \\
\hline TGX 1991-22F & $0.5 \mathrm{~d}$ & $1 \mathrm{~cd}$ \\
\hline SCS-1 & $\mathrm{ND}^{\mathrm{z}}$ & $2 a b$ \\
\hline
\end{tabular}

y Data based on a visual severity rating using a pretransformed rating scale from 0 to 5 , where $0=$ no visible symptoms, $1=1$ to $10 \%$ of the canopy affected, $2=11$ to $35 \%$ of the canopy affected, $3=36$ to $65 \%$ of the canopy affected, $4=66$ to $90 \%$ of the canopy affected, and $5=91$ to $100 \%$ of the canopy affected. Means followed by different letters within a column are significantly different $(\alpha=0.05)$.

z No data; the entry was already matured. 
recorded have been reported elsewhere, although many of them may be first reports of a specific disease in these locations. One of the diseases, bacterial tan spot, was found in most locations and was recently reported to occur for the first time on soybean in Africa based on samples from these trials (Pawlowski and Hartman 2019). The two diseases that are likely the most economically important in this region, red leaf blotch and soybean rust, occurred in some locations but not all, indicating that there may be some geographical and environmental constraints related to these pathogens. The goal of these evaluations was to provide information about susceptibility to diseases of the soybean entries in the Pan-African Trials to be used by breeders and others interested in the response of soybean genotypes to diseases.

A disorder or possibly a disease with limited information that we called mustard leaf spot exhibits yellowish spots on leaves (Fig. 1). These symptoms were found at high incidence levels but not at high severity levels. The cause of these symptoms has yet to be identified. This is the first report of these symptoms in Zambia, and based on these symptoms, the disorder has been described and named in Brazil as "mancha aureolada" (Anonymous 2012). The disorder has been seen in Illinois (Hartman, personal communication), Tanzania, and Uganda (Murithi, personal communication). Its impact on soybean productivity remains unknown.

The incidence of bacterial diseases was high in the trials, but the severity in general may have not been yield-limiting. However, due to their seedborne nature, these bacterial pathogens may affect seed quality and become widely distributed. In most cases, bacterial

Table 5. Soybean rust ratings averaged over two locations, (Chipata, Zambia, and Chitedze, Malawi). Data were recorded at Chipata and Chitedze, respectively, on March 14 and March 15, 2019.

\begin{tabular}{|c|c|c|}
\hline Entry & Rust rating $(0-5)^{\mathrm{x}}$ & Reaction type $^{\mathrm{y}}$ \\
\hline Lukanga & $3.2 \mathrm{a}^{\mathrm{z}}$ & TAN \\
\hline Ibis 2000 & $3.1 \mathrm{ab}$ & TAN \\
\hline Dundee & $3.1 \mathrm{a}-\mathrm{c}$ & TAN \\
\hline Nasoko & $3.1 \mathrm{a}-\mathrm{c}$ & TAN \\
\hline SNK500 & $3.1 \mathrm{a}-\mathrm{c}$ & TAN \\
\hline S1187-5-37 & $3.0 \mathrm{a}-\mathrm{d}$ & TAN \\
\hline Clark 63k & $2.8 \mathrm{a}-\mathrm{e}$ & TAN \\
\hline Kaleya & $2.8 \mathrm{a}-\mathrm{e}$ & TAN \\
\hline S1079-6-7 & $2.8 \mathrm{a}-\mathrm{e}$ & TAN \\
\hline SC Spike & $2.6 \mathrm{a}-\mathrm{f}$ & TAN \\
\hline Makwacha & $2.6 \mathrm{a}-\mathrm{f}$ & TAN \\
\hline S1140-5-4 & $2.5 \mathrm{a}-\mathrm{g}$ & TAN \\
\hline TGX 1987-62F & $2.5 \mathrm{a}-\mathrm{g}$ & TAN \\
\hline Heron & $2.4 \mathrm{a}-\mathrm{h}$ & TAN \\
\hline TGx2014-16FM & $2.4 \mathrm{~b}-\mathrm{h}$ & TAN \\
\hline Egret & $2.4 \mathrm{~b}-\mathrm{i}$ & TAN \\
\hline TGX 1991-22F & $2.3 \mathrm{~b}-\mathrm{j}$ & TAN \\
\hline S1150-5-22 & $2.1 \mathrm{~b}-\mathrm{k}$ & TAN \\
\hline Panorama 291 & $2.1 \mathrm{c}-1$ & TAN \\
\hline Panorama 358 & $2.0 \mathrm{~d}-1$ & TAN \\
\hline Tikolore & $2.0 \mathrm{e}-1$ & TAN \\
\hline Panorama 3 & $1.7 \mathrm{f}-1$ & TAN \\
\hline Maksoy $5 \mathrm{~N}$ & $1.5 \mathrm{~g}-1$ & $\mathrm{RB}$ \\
\hline S1146-5-25 & $1.4 \mathrm{~h}-1$ & $\mathrm{RB}$ \\
\hline SC Sentinel & $1.4 \mathrm{i}-1$ & $\mathrm{RB}$ \\
\hline SC Saga & $1.3 \mathrm{j}-1$ & $\mathrm{RB}$ \\
\hline S1180-5-54 & $1.2 \mathrm{kl}$ & $\mathrm{RB}$ \\
\hline SC Signal & 1.11 & $\mathrm{RB}$ \\
\hline
\end{tabular}

$\overline{\mathrm{x}}$ Data based on a visual severity rating using a pretransformed rating scale from 0 to 5 , where $0=$ no visible symptoms, $1=1$ to $10 \%$ of the canopy affected, $2=11$ to $35 \%$ of the canopy affected, $3=36$ to $65 \%$ of the canopy affected, $4=66$ to $90 \%$ of the canopy affected, and $5=91$ to $100 \%$ of the canopy affected.

y TAN = fully susceptible reaction; RB = red brown resistant or partially resistant reaction (Miles et al. 2011). Data from Chitedze location only.

${ }^{\mathrm{z}}$ Means followed by different letters within a column are significantly different $(\alpha=0.05)$ blight and bacterial pustule on soybean are not limiting factors to yield if a source of resistance is deployed. However, there is less known about bacterial tan spot on soybean and its impact on yield. In the United States, there have been only a few recorded outbreaks of this disease on soybean, and it does not appear to be widespread (Harveson 2015). It is not known if any of the entries in the PanAfrican Trials have bacterial disease resistance because the severity of these diseases was not great enough to provide differential responses.

The severity of viruses and insect foliar feeding in the trials was relatively low. The lack of IFFD was likely due to the application of insecticide sprays, although no non-insecticide treatments were evaluated in these trials. In the case of viruses, no attempt was made to classify them based on field symptoms. More research needs to be done through sampling and using the appropriate methods to determine if any of the viral problems seen in these trials are unique. Severity levels were not great to provide any differential response of the Pan-African Trials entries.

The majority of fungal and fungal-like diseases observed in the trials, such as brown spot, Cercospora leaf blight, downy mildew, and frogeye leaf spot, had low disease severity and likely caused minimal yield losses. However, all of these diseases, if severe, can cause yield loss, as has been shown for target spot in Brazil with losses of up to $41 \%$ (Edwards Molina et al. 2019) and downy mildew of up to $43 \%$ (Silva et al. 2016).

Red leaf blotch is the only known disease recorded in the trials that appears to be indigenous to Africa (Hartman and Murithi 2018; Hartman et al. 1987). The pathogen causes significant yield losses up to $37 \%$, which have been documented in a number of trials (Datnoff et al. 1987; Hartman and Sinclair 1996). So far there are no known sources of resistance. Based on the evaluation of 23 "ancestral" soybean lines that provide most of the genes in the U.S. modern cultivars, it is unlikely that resistance exists in commercial cultivars (Tooley 2017). Additional evaluations for red leaf blotch resistance are needed in environments that typically have higher severity ratings and/or under controlled environmental conditions of inoculation to determine if there are resistance sources to this disease.

Table 6. The number of trials having significant $(P<0.05)$ pairwise correlations between growth stage and severity rating of foliar variables of soybean entries evaluated in seven soybean trials in Malawi and Zambia ( $n=22$ to 30 depending on the commonality of entries in the trial pair)

\begin{tabular}{|c|c|c|c|c|}
\hline \multirow[b]{2}{*}{ Foliar variable } & \multicolumn{2}{|c|}{$\begin{array}{l}\text { Correlation } \\
\text { coefficient }\end{array}$} & \multicolumn{2}{|c|}{$\begin{array}{c}\text { Correlation } \\
\text { coefficient }>0.5\end{array}$} \\
\hline & Positive & Negative & Positive & Negative \\
\hline \multicolumn{5}{|c|}{ GS and nonfungal $^{\mathrm{y}}$} \\
\hline GS & 7 & 0 & 7 & 0 \\
\hline MLS & 2 & 4 & 0 & 0 \\
\hline BB & 4 & 2 & 0 & 0 \\
\hline BP & 4 & 1 & 0 & 0 \\
\hline BTS & 2 & 2 & 2 & 0 \\
\hline Virus & 2 & 3 & 1 & 1 \\
\hline IFFD & 7 & 0 & 0 & 0 \\
\hline \multicolumn{5}{|c|}{ Fungal and fungal-like $\mathrm{z}$} \\
\hline BS & 3 & 0 & 3 & 0 \\
\hline CLB & 4 & 3 & 0 & 0 \\
\hline $\mathrm{DM}$ & 3 & 0 & 0 & 4 \\
\hline FELS & 1 & 4 & 0 & 0 \\
\hline RLB & 7 & 0 & 2 & 0 \\
\hline SBR & 1 & 0 & 1 & 0 \\
\hline TS & 1 & 1 & 0 & 0 \\
\hline
\end{tabular}

y GS = reproductive growth stage (Fehr et al. 1971); MLS = mustard leaf spot; $\mathrm{BB}=$ bacterial blight; $\mathrm{BP}=$ bacterial pustule $; \mathrm{BTS}=$ bacterial tan spot; Virus = virus-like symptoms of foliar mottling; and IFFD = insect foliar feeding damage.

${ }^{\mathrm{z}} \mathrm{BS}=$ brown spot; $\mathrm{CLB}=$ Cercospora leaf blight; $\mathrm{DM}=$ downy mildew; FELS = frogeye leaf spot; RLB = red leaf blotch; SBR = soybean rust; and $\mathrm{TS}=$ target spot. 
Soybean rust was recorded at only two of the seven locations, indicating the importance of having a number of trial sites to obtain useful data. Only six of the entries in the trials (Maksoy 5N, S1146-5-25, S1180-5-54, SC Saga, SC Sentinel, and SC Signal) had an RB response, indicating they have a Rpp gene or genes for resistance. Maksoy $5 \mathrm{~N}$, a selection from Maksoy $1 \mathrm{~N}$, has been used in as moderately resistant local check in Uganda (Oloka et al. 2008). The other five entries showing resistance are proprietary cultivars and experiment lines that are likely to carry known Rpp resistance alleles.

Plant maturity often plays a role in disease epidemics. Because our data were recorded only once at each location, we cannot fully understand how soybean maturity interacted with disease development. Because soybean maturities varied within a trial, we correlated disease rating to maturity and found in some cases that there was no significant correlation. Those that were significantly positively correlated included bacterial tan spot, viruses, brown spot, red leaf blotch, and soybean rust. Several reports indicate that severity increases for some soybean disease as the plant ages, as is the case for soybean rust (Hartman et al. 1991). The exception to that trend in our study was with downy mildew, in which rating decreased in plants that matured earlier, presumably due to more active green young tissue for the pathogen to colonize in plants that matured later. In our study, without multiple evaluations through the season, it was not possible to predict the trend of disease development over time, but it does point out that maturity should be considered when rating field plots for disease resistance when plant maturities vary.

In conclusion, our work provides a benchmark for the current status of soybean diseases in sub-Saharan Africa and a framework for further evaluation of soybean diseases in more Pan-African Trial locations (Santos 2019).

\section{Acknowledgments}

We appreciate the help of Rodrick Hamvumba, Stephen Mushimwa Chileshe, McDonald Nundwe, and Florence Kamwana for their assistance in managing the field trials and Drs. Roger Bowen and Michelle Pawlowski for editing the manuscript.

\section{Literature Cited}

Anonymous. 2012. Anomalia causa confusão nas lavouras de soja do Cerrado. J. Dia de Campo. http://diadecampo.com.br/zpublisher/materias/Materia.asp?id= $26343 \&$ secao $=$ Pacotes $\% 20$ Tecnol\%F3gicos\&c2=Soja

Chawla, S., Bowen, C. R., Slaminko, T. L., Hobbs, H. A., and Hartman, G. L. 2013. A public program to evaluate commercial soybean cultivars for pathogen and pest resistance. Plant Dis. 97:568-578.

Chigeza, G., Boahen, S., Gedil, M., Agoyi, E., Mushoriwa, H., Denwar, N., Gondwe, T., Tesfaye, A., Kamara, A., Alamu, O. E., and Chikoye, D. 2019. Public sector soybean (Glycine max) breeding: Advances in cultivar development in the African tropics. Plant Breed. 138:455-464.

Datnoff, L. E., Sinclair, J. B., and Naik, D. M. 1987. Effect of red leaf blotch on soybean yields in Zambia. Plant Dis. 71:132-135.

Edwards Molina, J. P., Paul, P. A., Amorim, L., da Silva, L. H. C. P., Siqueri, F. V., Borges, E. P., Campos, H. D., Venancio, W. S., Meyer, M. C., Martins, M. C., and Balardin, R. S. 2019. Effect of target spot on soybean yield and factors affecting this relationship. Plant Pathol. 68:107-115.

FAOSTAT. 2019. Statistical databases. Food and Agricultural Organization of the United Nations, Rome, Italy. http://www.fao.org/faostat/en/\#data/QC. Accessed on July 1, 2019.

Fehr, W., Caviness, C., Burmood, D., and Pennington, J. S. 1971. Stage of development descriptions for soybeans, Glycine max (L). Merrill. Crop Sci. 11:929-931.
Hartman, G., and Murithi, H. H. 2018. Coniothyrium glycines (red leaf blotch) Invasive Species Compendium Datasheet 17687. https://www.cabi.org/isc/ datasheet/17687. CABI, Wallingford, U.K.

Hartman, G. L. 2015. Worldwide importance of soybean pathogens and pests Pages 4-5 in: Compendium of Soybean Diseases and Pests. G. L. Hartman, J. C. Rupe, E. F. Sikora, L. L. Domier, J. A. Davis, and K. L. Steffey, eds. American Phytopathological Society, St. Paul, MN.

Hartman, G. L., McCormick, S., and O'Donnell, K. 2019. Trichotheceneproducing Fusarium species isolated from soybean roots in Ethiopia and Ghana and their pathogenicity on soybean. Plant Dis. 103:2070-2075.

Hartman, G. L., Bowen, C. R., Haudenshield, J. S., Fox, C., Cary, T. R., and Diers, B. W. 2015. Evaluation of disease and pest damage on soybean cultivars released from 1923 through 2008 under field conditions in central Illinois. Agron. J. 107:2373-2380.

Hartman, G. L., Datnoff, L. E., Levy, C., Sinclair, J. B., Cole, D., and Javaheri, F 1987. Red leaf blotch of soybeans. Plant Dis. 71:113-118.

Hartman, G. L., Haudenshield, J., Smith, K., Tooley, P., Shelton, J., Bulluck, R. Engle, J. S., Magarey, R., Royer, M., Sutker, E., Cardwell, K., Herman, T., and Datnoff, L. 2009. Recovery plan for red leaf blotch of soybean caused by Phoma glycinicola. http://www.ars.usda.gov/SP2UserFiles/Place/00000000/ opmp/Soybean\%20RLB\%20FINAL\%20July\%202009.pdf.

Hartman, G. L., and Murithi, H. M. 2019. Field Guide to African Soybean Diseases and Pests, V1.1. http://soybeaninnovationlab.illinois.edu/soybean-disease-diagnosticguide.

Hartman, G. L., and Sinclair, J. B. 1996. Red leaf blotch (Dactuliochaeta glycines) of soybeans (Glycine max) and its relationship to yield. Plant Pathol. 45:332-343.

Hartman, G. L., Wang, T. C., and Tschanz, A. T. 1991. Soybean rust development and the quantitative relationship between rust severity and soybean yield. Plant Dis. 75:596-600

Harveson, R. M. 2015. Bacterial wilt and tan spot. Pages 21-24 in: Compendium of Soybean Diseases and Pests. G. L. Hartman, J. C. Rupe, E. F. Sikora, L. L. Domier J. A. Davis, and K. L. Steffey, eds. American Phytopathological Society, St. Paul, MN

Haudenshield, J. S., Pawlowski, M., Miranda, C., and Hartman, G. L. 2018. First report of Paramyrothecium roridum causing Myrothecium leaf spot on soybean in Africa. Plant Dis. 102:2638.

Little, T., and Hills, F. 1978. Agricultural Experimentation: Design and Analysis. Wiley, New York, NY.

Miles, M. R., Bonde, M. R., Nester, S. E., Berner, D. K., Frederick, R. D., and Hartman, G. L. 2011. Characterizing resistance to Phakopsora pachyrhizi in soybean. Plant Dis. 95:577-581.

Murithi, H. M., Beed, F., Soko, M., Haudenshield, J. S., and Hartman, G. L. 2015 First report of Phakopsora pachyrhizi on soybean causing rust in Malawi. Plant Dis. 99:420.

Murithi, H. M., Haudenshield, J. S., Beed, F., Mahuku, G., Joosten, M. H. A. J., and Hartman, G. L. 2017. Virulence diversity of Phakopsora pachyrhizi isolates from East Africa compared to a geographically diverse collection. Plant Dis. 101:1194-1200.

Oloka, H. K., Tukamuhabwa, P., Sengooba, T., and Shanmugasundram, S. 2008. Reaction of exotic soybean germplasm to Phakopsora pachyrhizi in Uganda. Plant Dis. 92:1493-1496.

Pawlowski, M., and Hartman, G. L. 2019. First report of Curtobacterium flaccumfaciens pv. flaccumfaciens causing bacterial tan spot on soybean in Africa. Plant Dis. 103:2665.

Pawlowski, M., Murithi, H. H., Hailemariam, M., Tesfay, A. A., and Hartman, G. L. 2019. First report of Sclerotinia sclerotiorum causing stem rot in soybeans in Ethiopia. Plant Dis. 103:2676.

Santos, M. 2019. The state of soybeans in Africa: Soybean varieties in sub-Saharan Africa. farmdoc daily. https://farmdocdaily.illinois.edu/2019/08/the-state-ofsoybean-in-africa-soybean-varieties-in-sub-saharan-africa.html.

Shurtleff, W., and Aoyagi, A. 2009. History of Soybeans and Soyfoods in Africa (1857-2009): Extensively Annotated Bibliography and Sourcebook. Soyinfo Center, Lafayette, CA.

Silva, O. C. D., Santos, H. A. A., Pria, M. D., and Mio, L. L. M. D. 2016. Damage to soybean caused by downy mildew. Cienc. Rural 46:389-392.

Tooley, P. W. 2017. Development of an inoculation technique and the evaluation of soybean genotypes for resistance to Coniothyrium glycines. Plant Dis. 101: 1411-1416. 